\title{
8. Financing fuel cell market development: exploring the role of expectation dynamics in venture capital investment
}

\author{
Rolf Wüstenhagen, Robert Wuebker, \\ Mary Jean Bürer and Dale Goddard
}

\section{INTRODUCTION}

The widespread adoption of fuel cell technology depends on a set of actors often neglected in research on the introduction and diffusion of breakthrough innovation: namely, the investors that fi nance that innovative activity. While policy-makers and scholars have traditionally focused on large, public companies and internal capital markets and their role in the innovation process, a small but growing body of work suggests that this activity may be at its most potent when harnessed to entrepreneurial activity. Research also suggests that venture capital can play an important role in the commercialization of breakthrough sustainable energy technologies - solutions that will reduce dependence on oil and stem the effects of climate change (Moore and Wüstenhagen, 2004; O'Rourke and Parker, 2006; Wüstenhagen and Teppo, 2006).

After a slow start, venture capitalists have accelerated investment into promising energy-related ventures. Less than eight years after Diefendorf (2000) examined why the venture-capital community had lost interest in the sustainable energy market, the emerging segment has become the third-largest venture-capital investment category behind software and biotechnology. In 2006, the cleantech sector contained \$US 2.6 B (€1.7 B) in invested capital, representing $11 \%$ of all venture-capital investment for that year and an increase of $78 \%$ over 2005 . The growth in investment in 2006 was driven almost entirely by investments in the energy technology sector, within which clean-energy generation (wind, solar, and so on) dominated the other three subsectors, capturing almost $50 \%$ of invested capital. Fuel cell investment lagged behind other clean-energy generation 
solutions substantially. Research conducted by the National Venture Capital Association in 2007 finds that $80 \%$ of venture capitalists expect that cleantech will attract even higher levels of funding in 2008 , and $61 \%$ of the venture capitalists they surveyed now believe that the cleantech industry is, or soon will be, overvalued (NVCA, 2007).

For those familiar with the venture-capital cycle, these facts are not surprising. The concern over the dearth of cleantech funding in 2002 has progressed to worries about capital oversupply in 2007, another example of the well-documented volatility of the venture-capital industry. These swings lead to situations where too many competing companies are funded, followed by others where there is not enough capital to go around. The real-world implications to innovation - what gets funded, when and why - are challenging to measure but also difficult to understate. The boom of 1998-2000 provides an example. Funding during those years grew dramatically, concentrated in two areas (the telecommunications and Internet industries) and accounted for 57\% of all investments in 1999. As Gompers et al. (2008, p. 2) point out, during boom phases such as 1998-2000 'many apparently promising areas languished unfunded . . . as venture capitalists raced to focus on the most visible and popular investment areas'.

Why do wild swings in venture-capital funding cycles exist and persist? Extant research provides two perspectives on this puzzle. One view, drawing from insights from behavioural finance, starts with the presumption that venture-capital investors are less than fully rational. Factors such as built-in cognitive bias or contextual factors such as career concerns significantly influence investment decisions (Baker et al., 2007; Scharfstein and Stein, 1990). A contrasting view is that the volatility of the venturecapital industry stems not from irrational underreaction or overreaction, but from the inherent volatility of the fundamentals (Gompers et al., 2008). According to this view, the alleged overreaction is simply a rational response to changes in investment opportunities.

The pattern of cleantech investment in general and investment in fuel cells in particular does not lay claim to straightforward and rational riskreturn characteristics. Taking stationary fuel cells as an example, we see a pattern of investments that can be described as a sequence of (seemingly irrational) exuberance and (seemingly irrational) austerity, a pattern that has also been referred to as a 'hype cycle' (Fenn, 2008). We suggest that if all financial actors behaved rationally, such hype cycles would not exist. That they do exist suggests two things, namely, (a) that investment behaviour is not always rational, and (b) that the return of venture investments depends on the expectations of other investors as much as on the fundamental value created by the firms in which they invest. Asking venture capitalists this question directly indicates that, at the very least, 
past performance may influence present-day investment decision-making. As an example, Diefendorf (2000) reported that many venture capitalists remembered the last energy investment 'boom cycle' (for example, investment in early fuel cell companies) and as a result were unwilling to engage in a repeat performance, indicating that our understanding of the processes by which venture capitalists invest, create value and contribute to the innovation process remains incomplete. The purpose of this chapter is to investigate this issue in greater depth, detailing the results of our preliminary investigation and providing suggestions as to future research.

In this chapter, we reconstruct some of the behavioural aspects of observed investment patterns in fuel cell technologies. This chapter contributes to current conversations in science and technology studies, providing additional information about an important yet somewhat neglected set of actors involved in the diffusion of innovative technologies. Our work also represents an initial step toward a richer and more nuanced understanding of venture-capital investment behaviour that incorporates insights from behavioural finance.

The remainder of this chapter is organized as follows. Section 2 provides a review of the literature about the role of financial actors in newtechnology development and the importance of expectation dynamics investigate the fuel cell investment cycle at an industry level, providing a descriptive analysis of investment flows in the fuel cell sector over the past decade. This analysis provides a context in which to examine how investment in a new sector diverges from what would be expected, and allows us to draw tentative conjectures as to why this could be the case. In section 4 , we move to the level of the venture-capital firm and in particular the individual investor, and examine the results from interviews with senior venture-capital investment professionals in the fuel cell sector. The Final section concludes the chapter with implications for policymakers, investors, and entrepreneurs and provides suggestions for further research.

\section{LITERATURE REVIEW}

The literature on science and technology provides insight about the inception, development and commercialization of breakthrough innovation. Scholars in this stream of research typically use models derived from evolutionary economics to detail how innovation systems move from invention to dominant design using a variety and selection model (Nelson and Winter, 1982). Utterback (1994) describes a view of this industry evolution - driven by innovation - as a dynamic mode of innovation and interdependent industrial change commonly referred to as the 'S-curve'. 
The emergence of a dominant design is an important feature of this model as it significantly impacts the industry participants, often remaking the industry as the underlying fundamentals change and physical and human capital is reallocated from incumbents to entrants (Schumpeter, 1934).

The road to a dominant design is rarely straightforward or pure. As the literature on innovation systems details, various actors and institutional features can contour both the variety and the selection mechanisms that eventually lead to the 'dominant design', and this may result more from initial conditions or influences in the innovation process 'black box' than from processes of variation and selection. This literature has explored the role of entrepreneurial firms, incumbent firms, and policy-making entities and how they influence the dominant design itself or how quickly it is adopted.

While the literature on both the innovation systems and science and technology provides a rich picture of the innovators and actors at the level of the firm and industry segment, neither literature has explored the role of an important institutional feature - that of the capital markets - a glaring omission in that venture capitalists are crucial to breakthrough innovation.

\section{Venture capital and breakthrough innovation}

Venture capitalists find, fund and assist entrepreneurs whose firms are instruments of Schumpeter's (1939) 'creative destruction' and 'creation of new economic spaces'. As an industry, venture capital assumes the risk of investing in next-generation technologies and services, frequently at early stages of their development, in order to reap the economic rents generated by successful new firms. Over the past twenty-five years, the venture-capital industry has experienced explosive growth, developing into an important financial intermediary facilitating the start and growth of 'high-impact entrepreneurs' (Acs, 2008). As part of their role in the financial system, venture capitalists are agents of innovation-driven economic growth: they evaluate prospective entrepreneurs, mobilize savings to finance the most promising productivity-enhancing activities, diversify the risks associated with innovative activities, and reveal the prospective profits from engaging in innovative activity rather than the production of existing goods and services. It is argued, therefore, that an active venture-capital market improves the probability of breakthrough innovation, and empirical work testing this hypothesis supports this perspective (Dushnitsky and Lenox, 2005; Florida and Smith, 1990; Kortum and Lerner, 2000; Lerner, 2002). The impact of venture capital and its capacity to initiate and shape innovative activity is responsible for a substantial and thriving stream of cross-disciplinary research (Cornelius and Persson, 2006). 
A rich literature has conceptualized and documented how venturecapital firms raise the funds they invest, screen prospective projects, make investments and exit portfolio firms. We have a clear picture of the venture capitalist as an active investor who assumes a monitoring role for the innovative entrepreneurial firm and uses specialized knowledge to add value to venture-backed firms. Venture capitalists provide these entrepreneurs and their new ventures with funding, strategic advice, contacts and reputation. They bring to the table a host of financial and organizational knowledge, including screening capabilities, due-diligence processes, staged financing, syndication of investments, compensation contracts, covenants and restrictions, and corporate governance practices. In so doing, venture capitalists help bring innovation to market, overcoming the uncertainty and risk associated with its development and commercialization.

A striking feature of venture-capital investment is how little the practice has changed over the last five hundred years. The risks faced by the three seed investors in Johannes Gutenberg's movable-type press are largely the same risks noted by the first investors in Apple Computer and Genentech. Venture investments have always been made under unusually high levels of uncertainty. Firms receive venture financing at early stages of development to pursue novel technologies, untapped markets and unproven business models. Entrepreneurs have always had more information about the true state of the technology the business opportunity and management capability than investors (Christensen et al., 2009). Financiers continue to worry about whether the entrepreneur will squander their investment. The structural and contractual mechanisms used by today's venture capitalists to mitigate those risks are strikingly similar to those in Babylon, Asia and medieval Europe centuries ago. We can observe in the historical record the consistent application of incentives and controls familiar to modern venture- capital firms: staged capital infusions, syndication, incentive contracts and intensive local monitoring.

\section{Expectation dynamics and the innovation process}

The literature on science and technology studies details the impact of expectation dynamics on innovation processes. These expectations can be product or project specific, generalized expectations about the future of the technological field, or interpretive schemes or frames referring to the role of a particular technology in society (Ruef and Markard, forthcoming). Scholars in this tradition have suggested that enthusiasm concerning a promising technology can add momentum to the innovation process in terms of both its speed and technological development (Borup et al., 2006). 
From this perspective, a 'hype cycle' can be conceived as the dynamic set of shared expectations which cannot be ignored by the actors engaged in the innovation process. These expectations have a certain path dependence and gravity to them and thus have significant importance, as they influence access to resources for innovators. Attracting both talent and capital seems to be easier in industries or firms where expectations are high. Thus it is not surprising to discover that innovators are aware of these expectation dynamics and use them to their advantage, communicating (and sometimes overstating) the promise of the technology in order to garner these resources (Guice, 1999).

Ruef and Markard (Ruef and Markard, forthcoming) address the question of what happens 'after the hype,' examining how missed expectations influence future innovation processes in the fuel cell industry. However, being on the wrong side of expectations can occur both when overhyped expectations do not materialize (for example, at the tail end of the cycle) but also at its earliest stages, when variation has not produced a dominant design. Innovators solving the same problem using different technology must now explain why their novelty-upon-novelty (that is, risk-upon-risk) is a more appropriate candidate for a dominant design. Expectations, once shared broadly by the actors engaged in the innovation process, can no longer be ignored (van Lente, 1993). Expectation dynamics are of crucial interest at the earliest stages of technology-driven innovation, as the selected architectures and technical approaches may create evolutionary lock-in and have path-dependent properties.

As detailed above, venture capitalists are an actor in a well-developed innovation system and involved close to the beginning of an innovation cycle. The recent wave of interest in the energy sector provides interesting insight into the potential power of the venture-capital industry to shape access to resources to certain innovations at their earliest stages of development. An article in Wired Magazine in 2007 (Greenwald, 2007) charts the migration of management talent and venture-capital interest away from enterprise software and Internet applications from 2006 forward, perhaps spurred in part by big venture bets on renewables made by a small number of high-profile Silicon Valley venture capitalists such as John Doerr and Vinod Khosla. Thus, the role of the venture capitalist in the innovation process is important to examine, and - given the industry's early involvement and influence on innovation - may have an outsized impact.

\section{Expectation dynamics and venture-capital investment decisions}

Financial theory has traditionally been based on the assumption that the 'representative agent' in the economy is rational in two ways: the agent 
(1) makes decisions that maximize their expected utility and (2) makes unbiased forecasts about the future (Thaler, 1999). Pioneering work by Kahneman and Tversky (Kahneman and Tversky, 1979) convincingly proves that these assumptions are far from compelling when applied to decisions under uncertainty. In real life, decision-makers differ from conventional assumptions of economic theory in that they exhibit a number of cognitive biases. A significant effect of these biases is that they lead to conservatism in adjusting to new information (Kahneman and Tversky, 1979; Kahneman, 2003). Building on these insights, Kahneman and Tversky (1979) drew attention to anomalies in choices under risky prospects, demonstrating that losses are weighted differently than gains, and that expected losses and gains, rather than final assets, explain investment behaviour. These findings are touchstones for research in the emerging area of behavioural finance, which analyses the investment decisions that are based on these heuristics and biases.

Empirical evidence for the theoretical phenomena described by Kahneman and Tversky and the stream of behavioural economic research built on their insights has been found in various areas, including investor behaviour in stock markets (Chan and Lakonishok, 2004; Jordan and Kaas, 2002; Lakonishok et al., 1994), currency speculation (Bikhchandani et al., 1992; Bikhchandani and Sharma, 2001; Froot et al., 1992), and managerial decision-making (McNamara and Bromiley, 1999). The surveys by Baker et al. (2007) and Barberis and Thaler (2003) are useful points of departure for a detailed understanding of the development of the field and the current state of research.

In their survey of behavioural finance, Barberis and Thaler (2003) further detail what they call the 'building blocks' of the field, focusing on 'limits to arbitrage' (rational traders cannot undo the activity of lessrational traders) and 'psychology' (which focuses on built-in cognitive biases that result in deviations from full rationality). Both building blocks are of interest in this chapter. In the context of venture capital, Shepherd (1999) and Zacharakis and Shepherd (2001) found evidence for overconfidence and availability bias among a set of Australian and US venture capitalists, respectively, and Shepherd et al. (2003) indicated that decision accuracy of venture capitalists as a function of their experience appeared to decrease, rather than increase beyond a certain point. Taken broadly, the evidence suggests that social cognitive and emotional biases impact investment decisions. In turn, these decisions influence market prices, returns and the allocation of resources.

Cognitive biases can often have strong aggregate effects. However, the studies examining bias in venture-capital decision-making have focused on the individual decision-maker and the evaluation of either an investment 
opportunity (Shepherd, 1999) or the entrepreneurial team (for example, research on similarity bias by Franke et al., 2006). In contrast, little attention has been paid to how individual venture capitalists choose the industries in which they invest (Wüstenhagen and Teppo, 2006) - evaluating the opportunity space at the individual level - or the influence of other cognitive biases that have aggregate effects. Despite the fact that venturecapitalist activity is, at heart, an investment process, it is puzzling that there has been little theoretical or empirical work identifying and testing how limits to arbitrage or psychology impacts venture-capital decisionmaking. Our work seeks to rectify this by incorporating additional insights from behavioural finance beyond individual-level biases, shifting the level of analysis from the opportunity (narrowly defined) to the development of an industry and the innovation processes within that industry.

Behavioural finance, with its theoretical foundations resting as much on social psychology within large groups as on the psychology of individuals, seems to us to have the potential to contribute substantially to our understanding of venture capital and its influence on the innovation cycle. Individual biases cannot explain a number of known phenomena found in behavioural finance: for example, grandstanding, herding and groupthink. A behavioural-finance perspective provides us with a rich theoretical context in which to explore other aspects of the venture-capital process, including the decision to sell a portfolio firm or take the firm public; or whether and when to invest in a disruptive technology or market. Specifically, we are interested in the implications of: (1) aggregate-level biases on the innovation process and the search for the dominant design, specifically the presence of hype cycles; and (2) whether venture capitalists are aware of these cycles, and what actions they take to either mitigate the risk associated with them or shape them to their benefit.

\section{AN ANALYSIS OF THE FUEL CELL INVESTMENT CYCLE}

We begin our analysis by examining the investment characteristics of the fuel cell industry. We need a descriptive analysis of the industry to understand whether industry dynamics exhibit cyclicality like other segments, and if so, whether that applies to both private and public investment.

\section{Data and Sample}

We used the following data to perform our analysis: publicly available information for stock-price returns; Venture Expert for venture-capital 
investment data; and publicly available information about firms, including filing documents and press releases. Data on publicly-traded firms is compiled from the Center for Research in Security Prices (CRSP), Graduate School of Business, University of Chicago. The CRSP database includes monthly and daily price quotations for common stocks, excluding preferred stock and including American Depository Receipts (ADRs), traded on the New York and American stock exchanges and NASDAQ. The level of analysis is market capitalization, based on monthly stock prices (adjusted for stock splits) and outstanding shares.

Market capitalization summaries combine the market capitalizations of the ten largest publicly-traded fuel cell companies. This analysis excluded companies for whom fuel-cell endeavours represented a minority of the firm's spending or revenues. As a result, further analysis of corporate fuel cell R\&D spending could further illuminate this topic.

The primary data set for venture investment is compiled from the SDC VentureXpert database provided by Thomson Venture Economics. The sample covers a ten-year period from 1997 to 2007. The level of analysis is the venture-capital firm and the unit of analysis is the funding round. VentureXpert data are compiled from annual surveys of more than one thousand venture investors in the United States. These data are used extensively in venture-capital research (Gompers and Lerner, 2004; Guler and Guillen, 2007; Hochberg et al., 2007). The database contains basic business, geographic and financial information about venture-capital firms, funds and portfolio companies. It also contains detailed data on individual rounds of venture financing.

The sample drawn from the VentureXpert data includes venture-capital and generalist private equity firms in the United States, and excludes private equity organizations focused exclusively on leveraged and management buyouts and other private-equity transactions that do not focus on financing high-impact entrepreneurial firms. This sample also excludes round-level data for funding rounds focused on buyouts, bridge loans and acquisitions. The final sample size consists of 73 funding rounds for 27 fuel cell companies.

\section{Investment in Fuel Cell Companies}

Figure 8.1 details the market capitalization of publicly-traded fuel-cell companies from 1997 to 2007.

Investment patterns of publicly-traded fuel cell companies show a marked increase in December 1999. A possible explanation is that investors who anticipated the burst of the technology bubble were looking at fuel cells as the "next big thing'. The peak in fuel cell market capitalization 


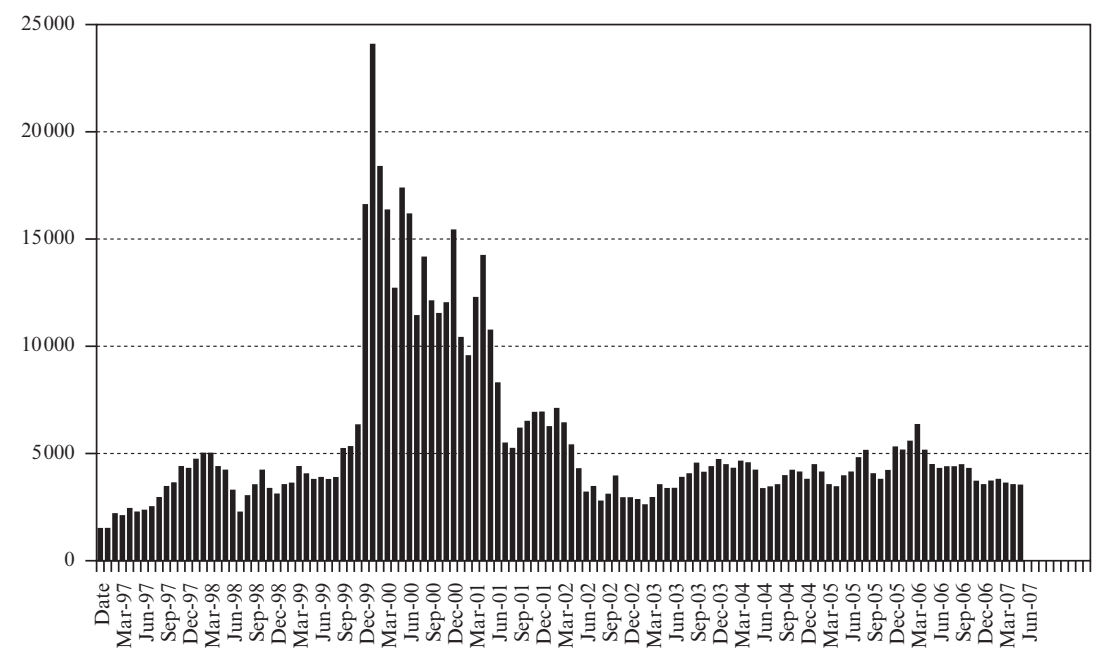

Figure 8.1 Market capitalization of publicly-traded fuel cell companies 1997-2007

also coincides with the hugely successful initial public offering (IPO) of Plug Power Inc. in November 1999 at $\$ 17$ per share. The stock peaked in March 2000 at almost $\$ 150$ per share before starting a steady decline that led to levels of $\$ 2$ per share in June 2008. While Plug Power may be an extreme example, it is somewhat symptomatic of the cycle of expectation dynamics that is mirrored in Figure 8.1. After the steep increase in late1999, market capitalizations of fuel cell firms returned to their prior levels by mid-2001, then took another dip followed by stasis ever since. We note that this also corresponds to typical patterns of industry development with a large number of new entrants before 2001, and then a phase of industry consolidation with an increasing number of mergers and acquisitions setting in after 2002. It is also interesting that while the initial rise of interest in fuel cells around 1999/2000 seemed to coincide with that of other clean-energy sectors such as wind and solar, there has been a divergence between those sectors in recent years (Usher, 2008). While investment in wind and solar has shown a significant rebound over the last 2-3 years, fuel cell firms have not reached similar levels of investment.

\section{Venture-Capital Investment in Fuel-Cell Companies}

In our exploration of indications for expectation dynamics in fuel-cell investing, we now turn to the venture-capital segment of the market. Figure 8.2 shows the level of venture-capital investment in fuel cell 


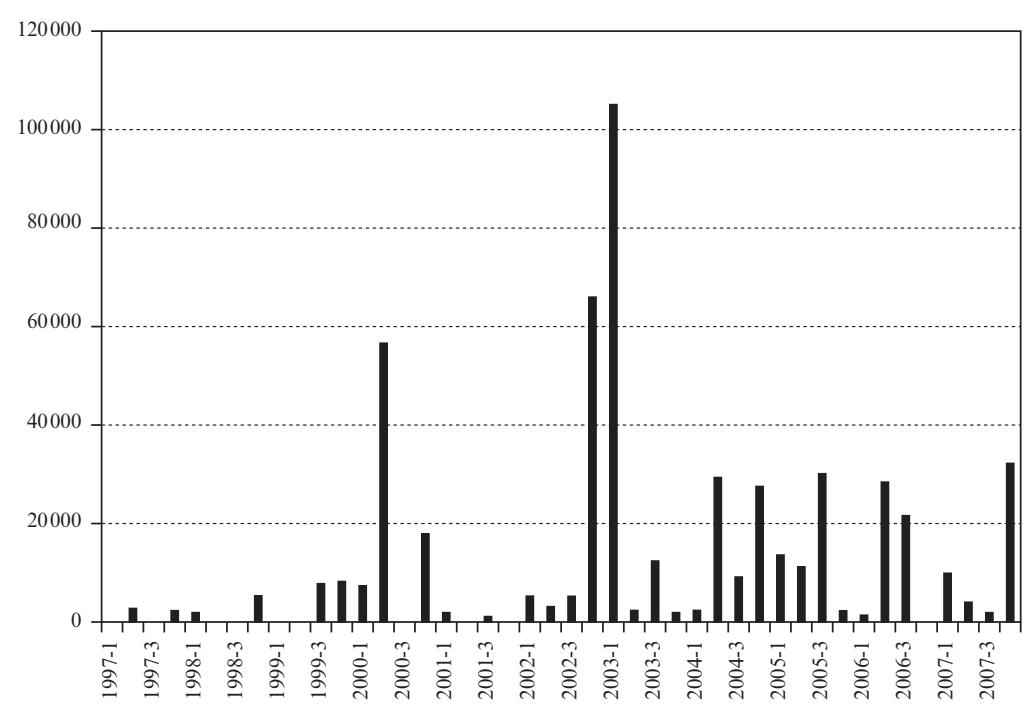

Figure 8.2 Level of venture investment in fuel cell companies 1997-2007

companies, based on data from VentureXpert as described above. The picture is less clear-cut than for market capitalization of publicly-traded fuel cell companies. On the one hand, there is a certain similarity in that there was a sudden increase in fuel cell venture-capital investment in the second quarter of 2000. This might indicate that, contrary to common assumptions about venture capitalists being early scouts of new technological trends but in line with Gompers et al.'s (2008) diagnosis of pro-cyclical behaviour of venture capitalists, quite a few venture-capital investors took the success of publicly-traded companies as a starting point for increasing their level of investment in fuel cell companies, hoping that the success story of Plug Power would lead to a series of more successful initial public offerings (IPOs). On the other hand, however, unlike the decreasing market capitalization of publicly-traded fuel cell companies post-2001, venture capitalists did invest substantial amounts of money in privately-held fuel cell companies in 2002-2007. This holds true even if we account for the peak in 2002/03 in Figure 8.2 as largely a result of one venture-capital firm (The Carlyle Group) making two large rounds of pre-IPO investment in one fuel cell firm (QinetiQ). A possible interpretation is that venture capitalists were hoping that investor sentiment for fuel cell companies would rebound similarly to other energy-technology sectors, hence reopening the window of opportunity for successful exits - a hope that has unfortunately remained largely unfulfilled. 
To conclude this descriptive analysis of ten years of fuel cell investment, we see that the fuel cell sector is indeed subject to some of the striking volatility that we have conceded at the outset of this chapter. Therefore, we seem to find some evidence for expectation dynamics influencing the performance of venture-capital investments in this sector. At the same time, digging deeper into the specific data about venture-capital investments and comparing them to market capitalization of publicly-traded fuel cell companies pointed to some limits to the influence of venture capitalists on how these expectation dynamics unfold. This is an interesting starting point for an in-depth, qualitative search for the drivers of these dynamics from the venture-capitalist's perspective.

\section{INTERVIEWS WITH FUEL CELL INVESTORS: TECHNOLOGY DEVELOPMENT AND EXPECTATION DYNAMICS}

Documenting the descriptive pattern in fuel cell investment is interesting, but does not provide sufficient insight into the larger question, which is: why volatility exists and persists and what role expectation dynamics play in explaining observed investment patterns? To address these underlying 'why' questions, we conducted a series of in-depth, semi-structured interviews in August 2007 with eight senior partners of venture-capital funds active in the fuel cell sector, as well as three other industry experts. Ten out of the eleven respondents were based in Europe, one in North America. Two of the eight venture-capital investors were corporate venture-capital funds. One of the venture-capital funds interviewed had carefully considered investment in fuel cell firms, but eventually decided against it. The interviews were conducted by phone, and then taped and transcribed.

\section{Are Venture-Capitalists Rational Investors or is There Evidence of a Hype Cycle?}

As a first observation, we were surprised by how frankly the venture capitalists in our interview sample conceded that behavioural factors play a role in their day-to-day analysis of industry sectors and investment opportunities. The responses of our interviewees showed some striking deviance from the neoclassical model of atomistic, individual market participants making rational assumptions based on complete information. Instead, based on our interviews, venture capitalists seem to be subject to some of the behavioural biases that have been described in other parts of the 
finance literature, such as herding. The following interview statements illustrate this point. Corporate Venture Capitalist 1: ' $10 \%$ of investors are investing based on their own research and credible due diligence and $90 \%$ are largely following the trends. But they often make money.' Venture Capitalist 3: 'Venture capitalists generally follow the pack.' Corporate Venture Capitalist 2: 'I think there are only a few knowledgeable venture capitalists in the fuel-cell area. Some money is just chasing.'

Another indication for herding in the venture-capital industry may be that several of our respondents hinted that people in 'their network' were influential in their investment decisions. Venture Capitalist 4: 'I am a board member of the European Fuel Cell Association and founding member of Fuel Cell Europe. I know a lot of academics. Someone in my network will tell me [about interesting opportunities].'

If indeed, as these exploratory interview results tend to show, a large proportion of venture-capital investors rely on others' opinions rather than on gathering their own independent information for forming an investment decision, we may then have come upon a possible explanation for the emergence of expectation dynamics in new-technology investing.

\section{How do Expectation Dynamics Influence Venture Capital Investment Performance?}

The interesting follow-up question then becomes: how the existence of expectation dynamics influences the investment performance of venture capitalists? The answer is not as straightforward as one might think. The performance of venture-capital investments is basically determined by the difference between the valuation of a portfolio firm at the time of investment versus at the time of exit (through IPO or trade sale). A purely rational investor who invests based on the underlying fundamentals of a company rather than on the expectations of other investors might miss out on the opportunities created by expectation dynamics. In a less-thanrational world, then, understanding where a given industry is on the hype cycle of escalating expectations, is key for investment performance. Venture Capitalist 3: 'I didn't get burned in fuel cells because we got out at the top of the hype. To avoid [getting burned] . . my strategy is to not talk about it ... go your own course.'

As much as it seems plausible that 'getting out at the top of the hype' is a promising strategy in a volatile market environment, the challenge for an investor is how to understand (in real-time) where the industry that he invests in is currently located on the hype cycle. An important indicator that seems to emerge from our interviews is the amount and nature of new 
entrants. Corporate Venture Capitalist 2: 'You want to pay attention to who gets involved. A lot of venture capitalists get involved with different backgrounds and think they can apply the venture-capital model and think it is all that it takes for cleantech and that is a sure sign of a hype.' Venture Capitalist 5: 'If you have a lot of new entrants in the market in the company side and the investment side - and in the cleantech sector, you have a lot of new entrants - and the traditional venture capitalists are entering and there are completely new ones founding a venture fund ... that's one sign.'

An inflow of new and less-informed investors seems to be a warning sign for experienced venture-capital investors that the peak of inflated expectations may be approaching, and that it is time for them to exit. A number of interviewees also pointed to linkages between the investment market and the general public, where an increasing amount of popular media coverage may be interpreted as an indicator for hype. Venture Capitalist 3: 'New people ... new venture capitalists . . . create the hype. Each new fund says we should get in this, they go to the newspaper ..., new venture capitalists create noise and then people start to follow that. I believe the good venture capitalists are kind of quiet about it.' Venture Capitalist 5: 'Another [sign for a hype] is a lot of newspaper articles.'

These findings point to the importance of linking different spheres of an innovation system to get a comprehensive picture of expectation dynamics in new-technology development.

\section{From Being Shaped by to Actively Shaping Expectations}

Reviewing the interview results so far, we argue that the performance of venture-capital investments is either shaped by expectation dynamics, or at the very least that venture capitalists are aware of the phenomena, believe that they matter, and act accordingly. Since our interviewees seemed to show a relatively high level of awareness of these phenomena, the question arises: whether venture capitalists act in ways that shape expectation dynamics in ways that are advantageous to them? Indeed, the fuel cell venture-capital investors that we surveyed seemed to acknowledge that they are not just passively experiencing these dynamics, but do take them into consideration in their business practices and use them to improve their performance and the performance of the firms they invest in. Venture Capitalist 3: 'That being said, I sometimes work on the sell side - help companies in the fund raising. I help them in getting forward on the wave of the hype to take advantage of it. That is the nature of our business.' Venture Capitalist 6: 'Yes, most venture capitalists are playing the game.' 
Subtle differences appeared when we looked at whether this shaping of expectations is something that venture capitalists do intentionally. Corporate Venture Capitalist 1: 'Not intentional but the venture capitalists can contribute [to hype creation]. One could debate that for a pre-IPO round people will be more willing to up the valuation at that point. Yes, venture capitalists do promote their companies.' Venture Capitalist 6: 'There have definitely been hypes around exits.' Venture Capitalist 3: 'There are a couple of venture capitalists that are very knowledgeable and I trust them and others that I wouldn't. I would not say they create hype cycle on purpose, but one success story creates another success story because people want to also get in when one is doing well. I remember we made a lot of noise about our investment that got 16 times the initial investment [in one year].'

Another interesting finding that emerges from these statements is that there seem to be certain times in the venture-capital investment cycle where active shaping of expectations is more likely to occur, namely, in the phase ahead of an exit, such as an IPO.

To summarize our findings from interviewing fuel-cell venture capitalists, we can confirm that expectation dynamics play an important role in influencing venture-capital investment behaviour. Our interviewees appeared to be aware of the impact of expectation dynamics on the performance of their investments, and consequently they seemed to be theorizing about current levels of expectation dynamics in the industry in which they invest, in order to spot early warning signs of peaking expectations, such as an inflow of new, uninformed investors. Finally, we also found evidence that venture capitalists are - to varying degrees of intentionality - actively shaping expectation dynamics. In sum, these findings seem to warrant a new perspective on venture-capital investing, which implies some important deviations from the conventional view of venture capitalists as rational, individualistic investors.

\section{CONCLUSIONS AND IMPLICATIONS FOR FURTHER RESEARCH}

The role of finance and investment is an important yet frequently overlooked piece of the innovation puzzle. It is our contention that financial actors are an important part of the innovation puzzle, and the exploratory research in which we have engaged extends the current discourse. Of course, this is just a starting point; much more research is required. Within the financial sector, venture capitalists are a particularly important group of actors when it comes to funding innovation. The traditional views of 
economics and capital markets do not completely explain investments in breakthrough technology. We would suggest that this is due to the high degree of technical and industry uncertainty. Thus, investment decisions are likely to be subject to behavioural effects and the influence of expectation dynamics.

In our industry-level analysis of fuel cell venture-capital investment, we show that this technology exemplifies how such expectation dynamics unfold, resulting in a hype cycle of exuberance followed by austerity. Our qualitative in-depth interviews with venture-capital investors in this sector took this analysis one step further beyond the level of description, disclosing some of the underlying reasons for the observed volatility in expectations and investment levels, such as marked inflows of uninformed investors at certain points in time. Our analysis also revealed that venture capitalists are keenly aware of these behavioural phenomena, take them into consideration, and to some extent consider actively shaping expectations as part of the way in which they add value. Given these apparent links between expectation dynamics and venture-capital investment performance, we conclude that there is an opportunity for a deep and substantive contribution to venture-capital research at the level of the individual investor/decision-maker (individual-level cognitive biases), at the level of the firm or as the abstract entity in the capital markets (shaping expectations as a value-added mechanism) and at the level of the industry (incorporating aggregate-level phenomena identified in the behavioural finance literature.

There are several avenues that our exploratory work described in this chapter are open for further research. First, our findings about the causal relationships behind expectation dynamics in venture-capital investing are largely based on a small number of single-event, in-depth, semi-structured interviews. Clearly there are opportunities to employ more sophisticated qualitative approaches to provide reliability and rigour. Future research could try to empirically measure some of the behavioural effects, such as herding, with larger samples and archival data. We think that newly-emerging sectors of the venture-capital industry, characterized by high levels of uncertainty, are a particularly fruitful environment for further research. Second, as in any herd, we suggest that there are leaders and followers in the broader venture-capital population. It would be interesting to improve our understanding of the different roles of these two groups in financing the development of new technology. Finally, our analysis was limited to one industry sector, fuel cells, and further research could extend this to other areas of venture-capital investing (for example, biofuels, nuclear energy), as well as non-venture-capital investments in the energy sector (for example, 
understanding the role of herding and expectation dynamics in recent oil-price developments).

We believe that our research has important implications for investors and policy-makers. In the case of investors, rather than exhorting them to behave purely rationally and try to avoid the pitfalls of expectation dynamics, we suggest that being aware of behavioural effects is crucial. An investor who understands where an industry is currently located on the hype cycle will be able to benefit from expectation dynamics, even if they appear to go beyond rational expectations, but he/she needs to be prepared to move quickly once a trend toward inflated expectations appears to be reversing. For policy-makers, two competing conclusions could be drawn, each of which has some rationale behind it. On the one hand, one might argue that public funding of innovation should be counter-cyclical, in order to correct for some of the 'irrational' expectation dynamics that seem to be characterizing private investment markets. Yet, on the other hand, one may also argue that the role of public policy could be to leverage private hypes, and hence to act pro-cyclically by increasing funding in those areas that are currently 'fashionable' among venture capitalists, based on the assumption that such hypes can give technologies a decisive boost toward large-scale commercialization that might not occur if investors were to rationally consider all the risks involved in developing uncertain new technologies.

Overall, research into the role of expectation dynamics in explaining investment in new technologies seems to be a fruitful field for further research. Given the substantial amount of investment that is needed for aligning our energy infrastructure with criteria of sustainable development, it is also a crucial element for informed decision-making by firms, investors and policy-makers.

\section{ACKNOWLEDGMENTS}

The authors wish to acknowledge funding from the Swiss National Science Foundation (contract no. 100012-113879) and a US National Science Foundation IGERT Fellowship, Fuel Cell Engineering, Science, and Entrepreneurship.

\section{REFERENCES}

Acs, Z.J. (2008), 'Foundations of High Impact Entrepreneurship', Foundations and Trends in Entrepreneurship, 4 (6), 535-620. 
Baker, M., R. Ruback and J. Wurgler (2007), 'Behavioral Corporate Finance: A Survey', in E. Eckbo (ed.), The Handbook of Corporate Finance: Empirical Corporate Finance, New York, NY: Elsevier/North Holland, pp. 145-86.

Barberis, N. and R. Thaler (2003), 'A Survey of Behavioral Finance', in G.M. Constantinides, M. Harris and R. Stulz (eds), Handbook of the Economics of Finance, Amsterdam, Netherlands: Elsevier, pp. 1051-121.

Bikhchandani, S. and S. Sharma (2001), 'Herd Behavior in Financial Markets', $I M F$, Staff Papers, 47 (3), 279-310.

Bikhchandani, S., D. Hirshleifer and I. Welch (1992), 'A Theory of Fads, Fashions, Customs and Cultural Change as Informational Cascades', Journal of Political Economy, 100 (5), 992-1026.

Borup, M., N. Brown, K. Konrad and H. Van Lente (2006), 'The Sociology of Expectations in Science and Technology', Technology Analysis and Strategic Management, 18 (3/4), 285-98.

Chan, L.K.C. and J. Lakonishok (2004), 'Value and Growth Investing: Review and Update', Financial Analysts Journal, 60 (1), 71-86.

Christensen, E., R. Wuebker and R. Wüstenhagen (2009), 'Of Acting Principals and Principal Agents: Goal Incongruence in the Venture Capitalist-Entrepreneur Relationship', International Journal of Entrepreneurship and Small Business, 7 (3), 367-88.

Cornelius, B. and O. Persson (2006), 'Who's Who in Venture Capital Research', Technovation, 26 (2), 142-50.

Diefendorf, S. (2000), 'Venture Capital and the Environmental Industry', Corporate Environmental Strategy, 7 (4), 388-99.

Dushnitsky, G. and M.J. Lenox (2005), 'When Do Incumbents Learn from Entrepreneurial Ventures? Corporate Venture Capital and Investing Firm Innovation Rates', Research Policy, 34 (5), 615-39.

Fenn, J. (2008), Understanding Gartner's Hype Cycles, Stanford, USA: The Gartner Group.

Florida, R. and D. Smith (1990), 'Venture Capital, Innovation and Economic Development', Economic Development Quarterly, 4 (4), 345-60.

Franke, N., M. Gruber, D. Harhoff and J. Henkel (2006), 'What You Are Is What You Like - Similarity Biases in Venture Capitalists' Evaluations of Start-up Teams', Journal of Business Venturing, 21 (6), 802-26.

Froot, K., D. Scharfstein and J. Stein (1992), 'Herd on the Street: Informational Efficiencies in a Market with Short-Term Speculation', Journal of Finance, 47 (4), 1461-84.

Gompers, P.A. and J. Lerner (2004), The Venture Capital Cycle, Cambridge, MA and London, UK: MIT Press.

Gompers, P., A. Kovner, J. Lerner and D. Scharfstein (2008), 'Venture Capital Investment Cycles: The Impact of Public Markets', Journal of Financial Economics, 87 (1), 1-23.

Greenwald, T. (2007), Gore, Joy See Green Economy Powered by Silicon Valley, 11 December 2007: Wired.

Guice, J. (1999), 'Designing the Future: The Culture of New Trends in Science and Technology', Research Policy, 28 (1), 81-98.

Guler, I. and M. Guillen (2007), 'Home-Country Networks, Intangible Assets, and Foreign Expansion', Academy of Management Best Paper Proceedings, Philadelphia, PA. 
Hochberg, Y.V., A. Ljungqvist and Y. Lu (2007), 'Whom You Know Matters: Venture Capital Networks and Investment Performance', Journal of Finance, 62 (1), 251-301.

Jordan, J. and K.P. Kaas (2002), 'Advertising in the Mutual Fund Business: The Role of Judgmental Heuristics in Private Investors' Evaluation of Risk and Return', Journal of Financial Services Marketing, 7 (2), 129-40.

Kahneman, D. (2003), 'Maps of Bounded Rationality: Psychology for Behavioral Economics', American Economic Review, 93 (5), 1449-75.

Kahneman, D. and A. Tversky (1979), 'Prospect Theory: An Analysis of Decisions under Risk', Econometrica, 47 (2), 263-91.

Kortum, S. and J. Lerner (2000), 'Assessing the Contribution of Venture Capital to Innovation', The Rand Journal of Economics, 31 (4), 674-92.

Lakonishok, J., A. Shleifer and R.W. Vishny (1994), 'Contrarian Investment, Extrapolation, and Risk', Journal of Finance, 49 (5), 1541-78.

Lerner, J. (2002), 'Venture Capital', in B. Steil, D.G. Victor and R.R. Nelson (eds), Technological Innovation and Economic Performance, Princeton, NJ: Princeton University Press, pp. 327-46.

McNamara, G. and P. Bromiley (1999), 'Risk and Return in Organization Decision Making', Academy of Management Journal, 42 (3), 330-339.

Moore, B. and R. Wüstenhagen (2004), 'Innovative and Sustainable Energy Technologies: The Role of Venture Capital', Business Strategy and the Environment, 13 (4), 235-45.

Nelson, R.R. and S. Winter (1982), An Evolutionary Theory of Economic Change, Cambridge, MA: Harvard Business School Press.

NVCA (2007), Venture Capitalists Predict 2008 Trends. Press Release, Dec. 17, 2007, USA: North American Venture Capital Association.

O'Rourke, A. and N. Parker (2006), 'Unearthing Cleantech: US and Canadian VC Investments into Cleantech between 1999 and 2005', Academy of Management Annual Meeting, Atlanta, USA, pp. 1-35.

Ruef, A. and J. Markard (forthcoming), 'What Happens after a Hype? How Changing Expectations Affected Innovation Activities in the Case of Stationary Fuel Cells', Technology Analysis and Strategic Management.

Scharfstein, D.S. and J.C. Stein (1990), 'Herd Behavior and Investment', The American Economic Review, 80 (3), 465-79.

Schumpeter, J.A. (1934), Theory of Economic Development, Cambridge, MA: Harvard University Press.

Schumpeter, J.A. (1939), Business Cycles: A Theoretical, Historical, and Statistical Analysis of the Capitalist Process, New York, NY: McGraw-Hill.

Shepherd, D.A. (1999), 'Venture Capitalists' Assessment of New Venture Survival', Management Science, 45 (5), 621-32.

Shepherd, D.A., A. Zacharakis and R.A. Baron (2003), 'VCs' Decision Processes: Evidence Suggesting More Experience May Not Always Be Better', Journal of Business Venturing, 18 (3), 381-401.

Thaler, R. (1999), 'The End of Behavioral Finance', Financial Analysts Journal, $55(6), 12-17$.

Usher, E. (2008), 'Global Investment in the Renewable Energy Sector', in O. Hohmeyer and T. Trittin (eds), Proceedings, Lübeck: IPCC Scoping Meeting on Renewable Energy Sources, pp. 147-54.

Utterback, J. (1994), Mastering the Dynamics of Innovation, Boston, MA: Harvard Business School Press. 
van Lente, H. (1993), Promising Technology. The Dynamics of Expectations in Technological Developments, Enschede: Doctoral thesis, University of Twente.

Wüstenhagen, R. and T. Teppo (2006), 'Do Venture Capitalists Really Invest in Good Industries? Risk-Return Perceptions and Path Dependence in the Emerging European Energy VC Market', International Journal of Technology Management, 34 (1/2), 63-87.

Zacharakis, A.L. and D.A. Shepherd (2001), 'The Nature of Information and Overconfidence on Venture Capitalists' Decision Making', Journal of Business Venturing, 16 (4), 311-32. 